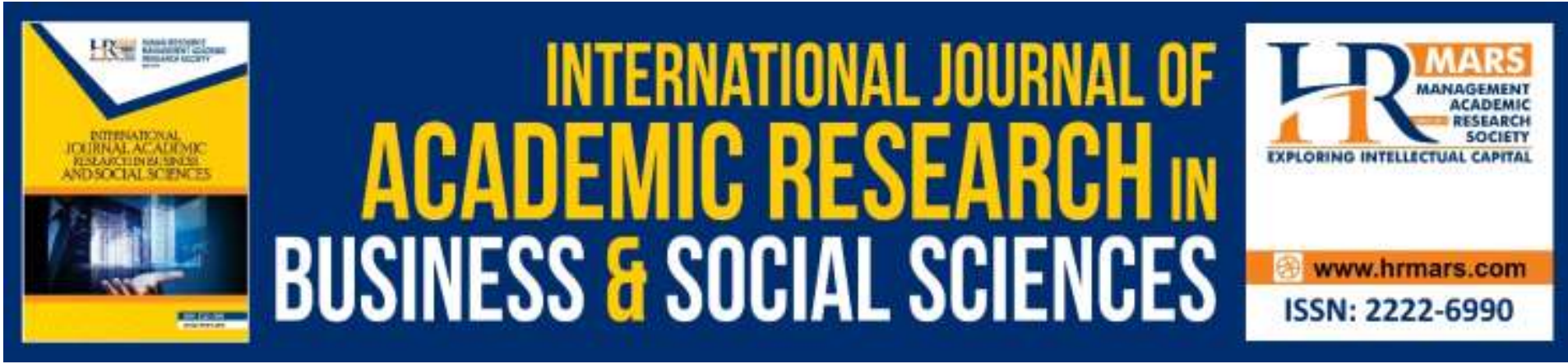

\title{
Dancing in Place at Rimbun Dahan: A Place to Create a Site- Specific Choreography
}

Nurulakmal Binti Abdul Wahid

To Link this Article: http://dx.doi.org/10.6007/IJARBSS/v10-i2/6937

DOI:10.6007/IJARBSS/v10-i2/6937

Received: 03 January 2020, Revised: 28 January 2020, Accepted: 02 February 2020

Published Online: 19 February 2020

In-Text Citation: (Wahid, 2020)

To Cite this Article: Wahid, N. B. A. (2020). Dancing in Place at Rimbun Dahan: A Place to Create a SiteSpecific Choreography. International Journal of Academic Research in Business and Social Sciences, 10(2), 391-400.

Copyright: (C) 2020 The Author(s)

Published by Human Resource Management Academic Research Society (www.hrmars.com) This article is published under the Creative Commons Attribution (CC BY 4.0) license. Anyone may reproduce, distribute, translate and create derivative works of this article (for both commercial and non-commercial purposes), subject to full attribution to the original publication and authors. The full terms of this license may be seen at: http://creativecommons.org/licences/by/4.0/legalcode

Vol. 10, No. 2, 2020, Pg. 391 - 400

http://hrmars.com/index.php/pages/detail/IJARBSS

JOURNAL HOMEPAGE

Full Terms \& Conditions of access and use can be found at http://hrmars.com/index.php/pages/detail/publication-ethics 


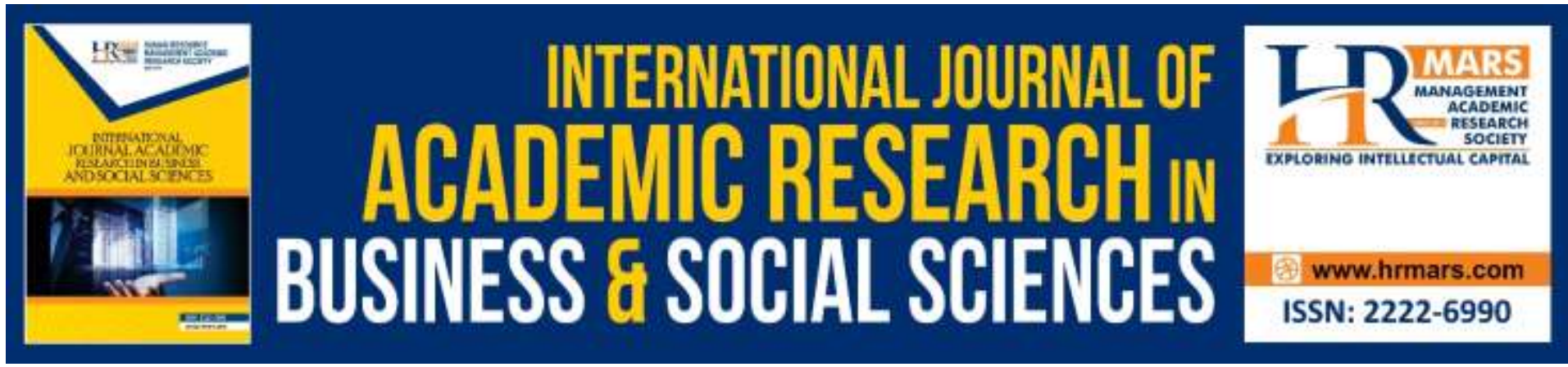

\title{
Dancing in Place at Rimbun Dahan: A Place to Create a Site-Specific Choreography
}

\author{
Nurulakmal Binti Abdul Wahid \\ School of Arts, Universiti Sains Malaysia (USM) \\ Email: nurulakmal@fmsp.upsi.edu.my
}

\begin{abstract}
Dancing in Place (DIP) is a dance program that presents site-specific dance work in Rimbun Dahan. This program will invite eight to ten local and international choreographers. These choreographers will produce site-specific dance work duration between eight and ten minutes. Choreographers are allowed to choose a space or site located in the Rimbun Dahan. Rimbun Dahan is a private land that has several houses, which is a modern and traditional Malay house proprietary by Hijjas Kasturi located in Kuang, Selangor. Rimbun Dahan surroundings consist of a studio for painters, dance studios, lounge artists, libraries, guest houses, swimming pools, art halls, tennis courts, flower gardens and art galleries that are under the management of Hijjas Kasturi's wife, Angela Kasturi. According to Hunter (2015), site-specific choreography is a dance performance resulting from a response to a site and performed at a specific location. This study aims to see how this program, Dancing in Place at Rimbun Dahan has become a platform for producing site-specific dance work. Observation and participatory observation methods were used in this study to obtain information about the program.
\end{abstract}

Keywords: Dancing in Place, Rimbun Dahan, Choreography, Site-specific

\section{Introduction}

Site-specific choreography is a contemporary dance work created and performed at a specific place chosen by a choreographer. Each site that has been chosen gives an idea and inspire the choreographer to produce a dance work. Site-specific choreography is a contemporary dance performance designed to be presented outside a specific place apart from the proscenium or black box stage. According to Kloetzel and Pavlik (2009), site-specific refers to a dance presented in a particular place/site and the environment will inspire the choreography process. In other words, site-specific is using an alternative space, for example from drain to the hotel lobby to form a motion, distance, theme, costume, music, and others to produce a performance.

Barbour and Hitchmough (2013), says that site-specific dance is to produces a relationship between site, performers and audiences in which the embodied, emotional and sensory experience of those present are engaged with the design, organic and structural features, as well as the social and cultural histories of the site. However, Kloetzel (2015) states, that site-specific performance relies on the terms of space and place as markers for discussing a performance's 
engagement with a site. Similarly, with Hunter (2015) states that site-specific performance is when the body gives forms to ideas and responses to the site as experienced by the choreographers and performers. Kloetzel and Hunter used the terms 'engagement or responses' to clarify the meaning of site-specific performance.

\section{Site-specific Choreography in Malaysia}

In 1960, Malaysian dancers and choreographers start continued their dance study in overseas. They studied classical ballet and some of them being the pioneer in Malaysia which is Lan, Lin, Teoh, Peng, Lum, Ying, Oh Eng Sim, Anna Kronenburg and Susan Manen (Gonzales, 2019). When returned to Malaysia, they helped to develop two dance genres which are ballet and contemporary dance. Lee Lan establishes a dance academy which is the Federal Academy of Ballet (FAB). Therefore, various works of ballet and contemporary dance are created and performed. Through contemporary dances knowledge, they conceptualized the site-specific choreography and presented at the Central Market, the beach area, the garden environment, the hotel swimming pool and many more. Thus, the involvement of site choreographers was Ang, D'cruz, Redza and many more. There are some of the site-specific choreography was created around the 1990s is Spirits are Closer at Twilight and Let's Rock by Lena Ang, The Story of Lotus Flower Dancing on Water and Kotak-Kotak, by Redza. Meanwhile, Redza still actively produces and performs site-specific choreography until now. Some of the dance work is Light (2011), Bridges \& Lima (2013), Wave \& Jetties (2015) and Moved by Padi (2016).

In the year of 2000, various festivals and programs were held in Malaysia where sitespecific dance works had become one of the performances in the program. Among the festivals held are Georgetown Festival, Melaka Arts and Performance Festival (MAPFest), Butterworth Fringe Festival, Butterworth Fringe Festival, Dancing in Place at Rimbun Dahan (RD), Dancing in Place City-Site in Damansara Performing Arts Centre (DPAC), Dancing in Place by Urbanscape in Chinatown, and several more festivals and programs held in Kuala Lumpur, Sarawak, Johor and Perak.

The development of site-specific choreography emerged by involving a new generation of Malaysian choreographer. Moreover, the involvement of the site choreographers and dancers can be seen through several festivals and programs. Then, various choreographies are produced by solo, duet, trio, quartet, and group. The choreographers who actively produced the site-specific choreography are Abas, Kadir, Tan, Xin, Govindarajoo, Vivan, Wahid, Tan Bee Hung, Tony Yap and many more.

\section{Rimbun Dahan, A Private Arts Centre}

Rimbun Dahan, is a private arts centre and the home of architect Kasturi and his wife Angela. Set on fourteen acres outside Kuala Lumpur, Malaysia, the compound of Rimbun Dahan is a centre for developing traditional and contemporary art forms. It features buildings designed by Hijjas Kasturi, as well as two early 20th-century traditional Malay houses from Perak and Penang, in an indigenous garden environment. There are also multiple artist studios, a dance studio, an artist lounge and library, and an underground art gallery. In Rimbun Dahan, generally, several arts program and residencies for the artist was organised which is resident artist, dance program, art exhibition, and others.

In brief, Rimbun Dahan focus is on supporting artists from within the Southeast Asian region, especially local Malaysian artists, while still providing space for international artists who are interested in engaging with Southeast Asian and Malaysian culture and art. 
Established in 1994, and has hosted more than 100 individuals who have benefited from the unique atmosphere of Rimbun Dahan to build their own artistic practice. They offer residencies for visual artists, dancers, choreographers, writers, arts managers, curators, and researchers as well as educational opportunities for students of architecture, ecology, and botany. Consequently, these residencies provide accommodation and workspace that far away from the bustle of the city for artists seeking solitude, silence or space to focus on their work as well as the opportunity to meet and do networking with other artists from a different country.

Furthermore, in Rimbun Dahan, a dance program is one of the annual events. This program consists of several programs such as residents of artists, dance workshops, Dancing in Place, presentations, and productions, artist collaboration, and other projects. Rimbun Dahan offers short residencies for contemporary dancers and choreographers. They are given full use of the dance studio and may be eligible for special support, including networking contacts, visits to local performances and assistance with producing a final showing or organising a workshop. Almost every year this dance program will be organised by Rimbun Dahan.

Table 1 : Dance Programme in Rimbun Dahan

\section{Program/Descriptions/Events}

1.Residency, contemporary dance practitioners (dancers, choreographers, dramaturg, programmers, scholars).

- Use of the dance studio at Rimbun Dahan

- $\quad$ Networking contacts with the local dance community.

- $\quad$ Escorted visits to local dance performances and events

- $\quad$ Simple production assistance for a final showing.

- $\quad$ Organization to give workshops to the local dance community.

2.Workshops, workshops taught by resident choreographers are and usually open to the local dance community.

- 2019: Contemporary Dance/Traditional Rhythms Workshop by Annalouise Paul

- 2016: Daniel Bear Davis

- 2013: One-Day Butoh Workshop by Yukio Waguri

- 2012: Contemporary Mask Workshop by Agung Gunawan

- 2012: T.H.E. Dance Company

- 2011: Dancing to Connect

- 2010: Yumi Umiumare

- 2010: Youth Dance Workshops by Elaine Pedley

- 2009: One Day of Workshops by Karen Lacey

- 2007-2009: Dance Day 
3.Performances \& Productions, previous work-in-progress or full-scale shows by Rimbun Dahan resident choreographers in theatres in Kuala Lumpur

- 2019: INSIDE OUT -- A Performative Exhibition by Isabelle Schad

- 2013: Caitlin Mackenzie \& Gabriel Comerford

- 2013: The BOW Project

- 2013: Stephen Shropshire

- 2012: Lina Limosani

- 2011: Riki von Falken

- 2010: Daniel Jaber

- 2010: Bodies Across Boundaries

- 2010: Arco Renz \& Amrita Performing Arts

- 2008: A Delicate Situation

4.Dancing in Place, is free for entry to the general public, and invites local and international dance and performing artists to engage with the architecture and garden environment of Rimbun Dahan by creating short site-specific works.

- Dancing in Place (2015-2019)

- Dancing in Place (2009-2010)

5.Others Project, the dance programme also conducts capacity-building and networking projects for local and regional dance practitioners and managers, in partnership with nonprofit organizations supporting dance and other cultural organizations

- 2019: Australian Choreographer Invites Collaborators

- 2015-2018: Southeast Asian Choreolab

- 2012: Work It!

- 2011: Opening of APIDC 2011

- 2011: Dance Film 'I Want to Remember'

- 2010: Gesek-Gosok by ASWARA Work Placement Students

\section{A Place to Create Site-specific Choreography}

Dancing in Place (DIP) one of the yearly events which will be held on early of the year either is in January or February or March. DIP is a program of dance performances are held on weekends and presents a site-specific choreography which held in Rimbun Dahan, Kuang, Selangor. Dancing in Place was organized by Dahan in collaboration with Alliance. Futhermore, this program was started in 2009 to 2011 and was stopped for three years (20122014). In 2015, DIP has been held on until now. DIP programs can be held annually in the Rimbun Dahan because it is private property. As it is the recommendation of Rimbun Dahan itself, the program does not require permission from certain parties. As I stated earlier, it has a variety of spaces or sites consisting of a traditional Malay and modern house, an underground art gallery, a flower garden, an art statue, a lake, a swimming pool, a tennis court, a playhouse, a dance studio and a range of small forest. DIP organizes, has chosen and invited the choreographer to produce a site-specific choreography. Also, choreographers are allowed to choose a particular site around Rimbun Dahan. 
In 2009, the program was held at the Rimbun Dahan, organized by Bilqis Hijjas and collaborated with MyDance Alliance. In the beginning, the DIP organizer has given the theme to the choreographer. The theme is associated with the selected work and site. However, in 2015 , the organizer did not set the theme for the performance. Among the choreographers that have been involved in the earlier of the DIP were Elaine Pedley, Lee Shee Hoe, Suhaili Michelin, Rathimalar Gavindarajoo, Bilqis Hijjas, Angela Goh and Fahmi Fazil. Every year, the organizers will invite eight to ten local and international choreographers to create a sitespecific choreography. Then, every year the involvement of the choreographer has increases and many young generations have involved. Throughout the program, various works of sitespecific were produced around Rimbun Dahan. The various site in the Rimbun Dahan area has given various ideas and inspires to choreographer.

A site or space used to create a site-specific choreography will develop creative processes, respond and implications to ideas, choreographers and dancers. Space is one of the main elements of dance. Space refers to a place or body of the dancers. There are two types of space which are general space and personal space. In site-specific choreography, a site has a common space that can inspire, ideas, identities, and creativity in the process of producing dance works. Meanwhile, personal space can be explored from the choreographer or dancer's body. They engage and respond to the site through the site background (historical) or used as material to explore the movement, emotion, performance structure and artistic.

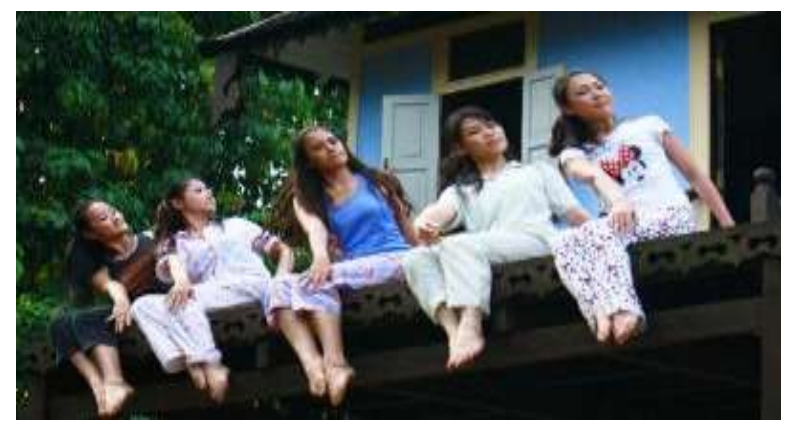

Photo 2: House Awakening by Bilqis Hijjas

DIP 2009 held in conjunction with the ART for Nature Visual Art exhibition, whose theme this year is a "TanahAirku" these works will lure us to unusual unexpected, or challenges us to view familiar places in new ways. Seven works were performed by seven choreographers, such as Angela Goh, Rathimalar, Suhaili, Fahmi Fadzil, Bilqis Hijjas, and Elaine Pedley. The works are presented in various sites, among them in the home of Uda Manap, swimming pools, in front of the dance studio, in the parking lot and the balai raya. The work of Quintessence by the Rathimalar Gavindarajoo which was performed solo in front of the dance studio. She uses soil and dry leaves in the surrounding area and planted herself in the soil and is doing it with dried leaves. These works relate to classical philosophy which is involved four elements water, fire, water, and earth. It explains the patterns of nature and the realm of human life makes a fifth. Apart from that, the work House Awakening by the Bilqis Hijjas, which was performed at the kitchen balcony of Uda and Manap House. This work performed by five dancers that the pyjamas. These works performed at the back-kitchen balcony and it gives an interesting view to the audience. Besides that, the used of the window to explore 
small movements using small parts of the body such as leg and arm shows how daily movement of waking up in the morning.

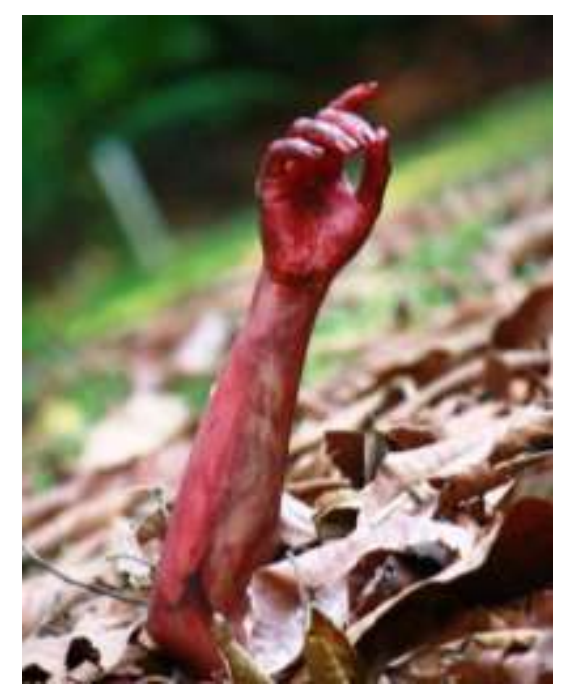

Photo 1: Quintessence by Rathimalar

Futhermore, DIP 2010, with the theme Cross-Pollination, encouraged choreographers to consider how different to working with artists from other disciplines, working with people from other cultures or abilities, or working in new environments or creates the potential for rich and vigorous hybridity's. In 2010, the performer included Kristine Nilsen Oma (Norway), Elvsa Wendi (Singapore), Donna (Philippines) and Scarlet Yu (Hong Kong), and as well nine choreographers from Malaysia including Rathimalar Govindarajoo, Gan Chih Pei, Nurulakmal Abdul Wahid, Leng Poh Gee, Elaine Pedley, Fahmi Fadzil, Chai Vivan and January Low. This year the involvement of the choreographer included local and international such as from Singapore, Norway, Philippines, and Hong Kong. In 2010, the number of Malaysian choreographers involves with this event increase and a lot of site-specific choreography had been performed. Chai Vivan restages her work Biji II at the Sakinah sculptor. I watched the first Biji in ASWARA that perform in experimental theatre. I think the restage at Rimbun Dahan is more interesting because of the site engages with the concept of the work. These works interpret about seeds that grow and come to life.

After 4 years of unorganized, in 2015, DIP was re-organized again until now. In 2015, there was twelve site-specific choreography presented. This time its involved local and international choreographers. There are six choreographers from abroad, Shahrin Johry (Singapore), Phittaya Phaefuang (Thailand), Joelle Jacinto (Philippines), Patrick Suzeau (USA) and Mia Cabalfin and Rhosam Prudenciado Jr. (Philippines). The Malaysian choreographer involved is Loke Poh Kim, Leng Poh Gee, Kathryn Tan, Azura Abal Abas, Nurulakmal Abdul Wahid, Lee Ren Xin, Rathimalar Gavindarajoo, Rithauddin Abdul Kadir, Judimar Hernández on, Gan Chih Pei and James Kan.

Starting from 2015, the organizer does not set any theme but choreographer still can choose the site. In 2015, the work Housewarming by Mia Cabalfin and Rhosam Prudenciado Jr. from the Philippines was performed in a duet at the Penang House. They performed in the living room of Penang house and the work has given a new experience to the audience. This 
work was unique because the ideas and concepts correspond and engage with the chosen site. According to Hunter (2015), a site-specific dance work presented on a site, the choreographer will be exploring the space, memory, or the original function of the site. Through this experience, the process of space construction will happen. This work has brought the audience to the imagination of everyday life in their respective own living rooms.

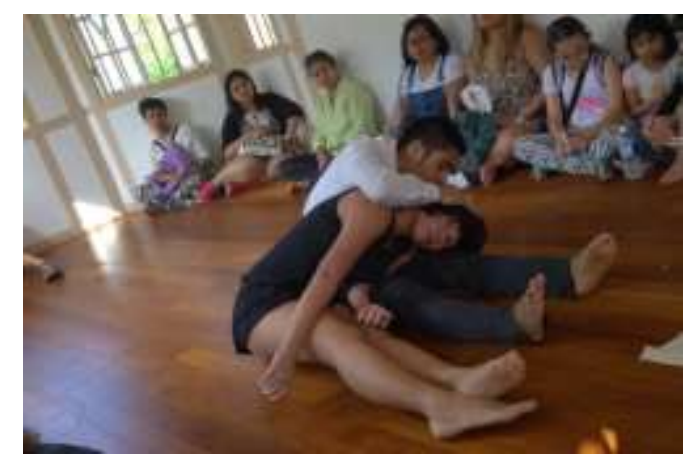

Photo 3: Housewarming by Mia and Rhosam

In 2015, a lot of site-specific dance work performed at surrounding Rimbun Dahan. Lee Ren Xin presented her work Asing-asing (B.E.D) at an underground gallery. These works using three mattresses and performed by three male dancers. This work is interesting because Ren Xin and her dancers explore all the space in that underground gallery. Besides, they interact with the audience and ask them to hold and pull the mattress and locate it in one place and another. Some audiences did not help or scared, maybe they think it might spoil the performance but some of them willing to help and enjoy joining the performance together.

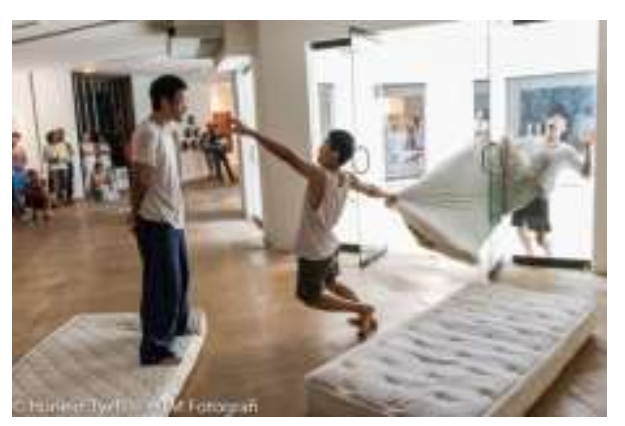

Photo 4: Asing-asing by Lee Ren Xin

This program continues until now, 2019. In 2017, Chai Vivan and Fione Chia collaborated on a Faux work presented in the Sakinah Sculptor or also known as the Bulatan Plong. Conceptualized 'picnic ', the work is about the experience of human vision that sometimes cannot identify which is right or wrong, or it is in between. In Faux, the choreographers used a lot of props such as picnic sets, mannequin, basket, flower and many more. The interaction between performers and audiences in Faux gives them felt funny and also uncomfortable. 


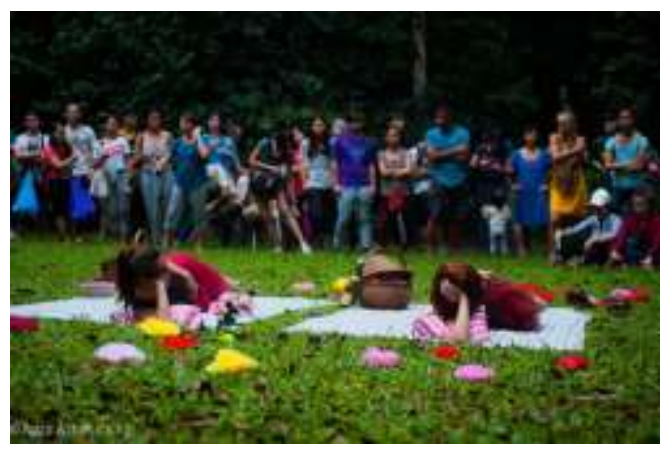

Photo 5: Faux by Chai Vivan and Fione Chia

\section{Conclusion}

Rimbun Dahan suitable location for exploring and producing site-specific choreographies. With a variety of sites consisting of traditional and modern houses, architecture, an underground gallery, lakes, swimming pools, botanical gardens and flowers, and the environment that nature has been able to inspire choreographers to produce ideas or an idea, expression in the sitespecific dance works.

Dancing in Place is one of the programs recommended by Rimbun Dahan to attract choreographers to produce site-specific dance works. Besides, the program also gives an opportunity to the outside community to enjoy the natural resources, architecture, statues, and visuals found in Rimbun Dahan. Since 2015 until now, 2019, it has increased the number of spectators for the site-specific choreography. The audience came from various backgrounds. The implications of this program can be seen through the recommendation of Dancing in Place CitySite 2017 at the Damansara Performing Arts Centre (DPAC) as well as Dancing in Place in Chinatown in conjunction with the Urbanscape Festival 2018. The brand has evolved and it has been an increase in the number of choreographers and dancers involved.

\section{References}

Hunter, V. (2012). 'Moving Sites';Transformation and Re-location in Site-specific Dance Performance. Routledge. University Of Surrey. Retrieved from

http://dx.doi.org/10.1080/10486801.2012.666740

Hunter, V. (2009). Site-Specific Dance Performance: The Investigation of a Creative Process. (Unpublished PhD thesis). Leeds, University of Leeds, United Kingdom

Kloetzel, M. (2017). Site and Re-Site: Early Efforts to Serialize Site Dance. Congress on Research in Dance. Retrieved from https:/www.cambridge.org/core. University of Calgary Library, on 01 May 2017

Kloetzel, M. (2010). Site-Specific Dance in a Corporate Landscape. Cambridge University Press. Kloetzel, M., and Pavlik, C. (2009). Site Dance: Choreographers and the Lure of Alternative Spaces. Gainesville: University of Florida

Dahan, R. (2019). Retrieved November 8, 2019, from http://rimbundahan.org/about/ 
INTERNATIONAL JOURNAL OF ACADEMIC RESEARCH IN BUSINESS AND SOCIAL SCIENCES Vol. 10, No. 2, Feb, 2020, E-ISSN: 2222-6990 @ 2020 HRMARS

Dancing in Place 2009. (2019). Retrieved November 9, 2019, from http://rimbundahan.org/dancing-in-place-2009/

Dancing in Place 2010. (2019, November 8). Retrieved from November 9, 2019, from http://rimbundahan.org/dancing-in-place-2010/

Dancing in Place 2015. (2019, November 8). Retrieved November 9, 2019, from http://rimbundahan.org/dancing-in-place-2015/

Dancing in Place 2017. (2019). Retrieved November 12, 2019, from http://rimbundahan.org/dancing-in-place-2017/ 